\title{
FROM THE LEVELS OF MEMORY TO THEIR INFO- TECHNICIST UNFOLDING IN THE INFORMATION SOCIETY
}

\author{
DOS NÍVEIS DA MEMÓRIA AOS SEUS DESDOBRAMENTOS \\ INFOTECNICISTAS NA SOCIEDADE DA INFORMAÇÃO
}

Mardochée Ogécime ${ }^{1}$

Rubens Alves da Silva ${ }^{2}$

\begin{abstract}
The present article consists of analyzing memory levels from the perspective of Assmann (2008). From a systematic review on the subject, is instituted a vision on the dimension of internal (neuronal), social and cultural memory in the human, material and immaterial relations between groups. A theoretical-analytic dialogue with History, Sociology, Anthropology, Social Psychology, Information Science and other areas of the Social Sciences is undertaken, which are presented not in a watertight manner, but which participate in the analysis of this polysemic object, formed not in the abstraction of the norm, but intertwined with the worlds of people and social dynamics. Next, the level of the cultural dimension of memory is related to the categories of the information society in its triple immersion: as an economic transition, political project and social norms, to discuss the technical dimension of memory whose modern tendency is characterized by the use / use and hyperindustrialization of 'mnemonic technology' for the performance and development of individuals, organizations and societies. Keywords: Memory-information. Culture-Society. Information Society. Mnemonic Technology. Information Science. Social Psychology.
\end{abstract}

\section{RESUMO}

0 presente artigo consiste em analisar os níveis da memória a partir da perspectiva de Assmann (2008). De uma revisão sistemática acerca da temática, institui-se uma visão sobre a dimensão da memória interna (neuronal), social e cultural nas relações humanas, materiais e imateriais entre grupos. Empreende-se um diálogo teórico-analítico com a História, a Sociologia, a Antropologia, a Ciência da Informação, a Psicologia Social e outras áreas das Ciências Sociais que são apresentadas não de modo estanque, mas que participam na análise deste objeto polissêmico, formado não na abstração da norma, mas entrelaçado aos mundos de pessoas e as dinâmicas sociais. Em seguida, relaciona-se o nível da dimensão cultural da memória com as categorias da sociedade da informação na sua tríplice imersão: como uma transição econômica, projeto político e normais sociais, para discutir a dimensão tecnicista da memória cuja tendência moderna se caracteriza pelo uso/utilização e hiperindustrialização de 'tecnologia mnêmica' pela performance e desenvolvimento dos indivíduos, organizações e sociedades.

Palavras-chave: Memória-Informação. Cultura-Sociedade. Sociedade da Informação. Tecnologia mnêmica. Ciência da informação. Psicologia Social.

Artigo recebido em 25/03/2019 e aceito para publicação em 20/05/2019.

1 Mestre em Ciência da Informação pela Universidade Federal da Bahia, Brasil. Doutorando no Programa de Pós-Graduação em Ciência da Informação da Universidade Federal de Minas Gerais, Brasil. Consultor do Nous Sense-making - NOUS, Brasil. E-mail: danymike123@yahoo.fr.

2 Doutor em Antropologia Social pela Universidade de São Paulo, Brasil. Professor da Escola de Ciência da Informação da Universidade Federal de Minas Gerais, Brasil. Pesquisador do Núcleo de Antropologia da Performance e do Drama da Universidade de São Paulo, Brasil. E-mail: rubensilva@eci.ufmg.br. 


\section{INTRODUCTION}

From the humanity's genesis, the inseparable relationship "Man-Society" is always defined by the dynamics of successive transformations in the Man's history in contact with social changes (centralization of the State as a social, cultural, political-economic apparatus for the organization of the social life, principle of differentiation and competitive logic between individuals, pacification of the habits) and technical evolutions. Behind these transforming operators, forces coexist, repel, and merge with each other. Significantly, each social segment describes an abjection properly attributed to representative vectors, which Bourdieu calls 'habitus' (JACINTHO SETTON, 2002).

These vectors constitute the acquired and consolidated norms whose conscious and unconscious bases are shared by a group. In fact, each adaptation of a habitus implies the implementation of known and shared codes, understood and accepted, under the logic that adaptation does not suffer uncontrolled changes. The habitus forms the common conduits; making them automatic and impersonal, meaningful without meaning. It is imposed by the 'social order', structurally, and is reproduced by each of the actors who are responsible for its maintenance in a cyclical way.

This is the undertaking of the expression of objective intention by the 'reactivation' of the 'lived' intention of the one who performs it. In this sense, the habitus forms a social and cultural patrimony that is expressed in the daily practices, whose property is to forge the individual posture and marks the personal condition and the social status. It inscribes the social subject in a particular group, widening the gap between social categories and personal statutes, adopting different habits. It is to this purpose that the values, norms, institutions and artifacts of a social segment tend to be "transmitted from generation to generation" (HOULT, 1969 apud UGORJI, 2012, p.13).

This kind of socio-cultural transmission seems inevitable for the social cohesion and the perpetuation of time. To build the community of tomorrow, it is essential that all the inhabitants of the community share the ideal of the community conceived as a civic and historical project, and find their common values; and the memory is this resource or support by which it seems possible to develop a whole sense of belonging to society as a factor of social cohesion. But it can also be the target of conflicts and capable of revealing and integrating the constitutive conflicts of the social. With regard to this approach, it is considered as a pluri / multidimensional category and a polysemic object of study of several levels according to the ideal reproduction of the researcher to undertake the essence of the social reality in question. 
As Ferdinand de Saussure has already said: "It is a bad method, that from the words to designate things" (SAUSSURE, 1968, p.42). It is on the interdisciplinary basis that we can better understand the specificities of objectives and concepts and perceive the convergences that lead to the polysemy of certain words. For, their use is made according to the conceptual needs found in the different fields of study. However, there are perhaps as many types and levels of memory as types of experience and resources of socio-cultural and political-economic nature; nevertheless, many classify them in different ways (LEZERD0, 1989).

These variations of use and conceptualization do not constitute an obstacle, but a research stimulus for problematization, characteristic of the social and human sciences. From this angle, the various acceptances of a term can interact in the complex conceptual architecture that requires the approach of a moving and polysemic object. Such is the case of memory research; a plural object that deserves to be approached in an interdisciplinary apprehension.

From this consideration, this article is based on the descriptive and functional character of the term 'memory' to expose the attribute of action articulated to its strata in the context of the article; and thus throw a multi-dimensional look at its properties. Else, the analysis that covers this article, through a deductive approach, is based on the analysis of the theoretical framework, from the description of the particularity of the concept of 'memory' and its levels from the perspective of Assmann (2008).

\section{FROM THE INDIVIDUAL MEMORY TO THE SOCIAL/COLLECTIVE MEMORY}

The relationship between individual memory and social / collective memory is very complex. In fact, rather than speaking of memory in the singular, it would seem better to speak of 'memories' in the plural: the notion of 'memory' refers to a diversity of interrelated, though well-differentiated, species of capacities, dimensions, and processes. In common language this notion is used to designate the human faculty to accompany the lived experiences and to be able to access them in the memory. This elementary approach here leads us to introduce with a biological approach to memory for a better understanding of the epistemological dimension that the present article proposes to weave.

From a neuroscientific approach, human memory can be searched from the neuropsychological point of view (functionalities and brain structures associated with memory itself or mental process) or from the physiological point of view (refers to memory as structure and its physiology) (NICOLAS , 2000). From these considerations, people can be considered as information-processing beings, which, 
like a system capable of processing, encoding, preserving and retrieving information in their naturally biological records or externalizing them in their technological extensions.

In this perspective, the main function of memory would be to provide human beings with the knowledge necessary to understand the world in which they live. Memory preserves and retrieves memories according to the present and updates our ideas, plans, and abilities in a world in constant transformation (LEFT, 2008).

In this way, it is assumed that if have something that characterizes the concept of memory at its internal (neuromental) level, it is his cognitive imperative (IZQUIERD0, 2008; NICOLAS, 2000; LOWENTHAL, 1998). Then, there is no memory without learning, and there is no learning without experience. As Aristotle has already said: "There is nothing in the intellect which has not been in the senses before" (MARSHALL, 1988, p.378, apud LEFT, 1989, p.2). It is considered that there is an implicit memory that includes habits, sensitization and classic conditioning, as well as perceptive and motor skills. In addition, there is an explicit memory that includes conscious memories about people, places, objects, and events (KREBS, 2013).

Thus, memory can be considered as the ability to acquire, store and retrieve information. We are who we are thanks to what we learn and remember. For without memory we could not perceive, learn or think, reason and express our ideas and we would not have a personal identity, because without memories it would be impossible to know who we are and our life would lose its objective meaning.

In the same way, individual memory can be considered as a human capacity to "reactivate, partially or totally, in a real or imaginary way, the events of the past" (TIBERGHEIN et al., 1900, p.4). It operates from a 'transitory' record and a supposedly permanent record (long-term memory), organizing and regulating mental representations, which constitute a 'semantic memory' with strong social utility and medium-size personalization (KREBS, 2013).

Individual memory, therefore, permanently produces "hierarchical and nested schemas that shape our participations and carry potential surprises. Its function is not only to reactivate the past, but also to detect novelties and enable learning" (TIBERGHEIN, et al., 1900, p.4). One can then consider individual memory as the creation / re-creation of a past - for example, through communications - and mediations of the broad understanding of the present and perspective of the future.

However, individual memory also depends on external or social parameters (EDWARDS; MIDDLETON, 1986), since the social and temporal weight influences information processing operations, and, memorizing certain functionalities and expectations related to social situations is similar to the 
memorization of more or less standardized collective contexts and functions (BROWN; KULIK, 1977). This shows that, at the social level, with regard to groups and societies:

the role of external symbols becomes increasingly important, because groups that do not have memories tend to construct them by means of things that function as memories, such as monuments, museums, libraries, archives, and other mnemonic institutions. (ASSMANN, A., 2006, apud ASSMANN, 2016, p.119, our translation).

Moreover, the absence of a general distinction between collective and social records (ASKÉVISLEHERPEUX, 1997; JAISSON, 1999; WINTREBERT, 2000) still allows us to anticipate Halbwachs's (2006) perspective with his conception of social memory: of the common memories that we conjure together; of a reference to national or group level events; to belong to a group with shared references and common traditions, to which they are added to social representations (PÁEZ, INSUA, VERGARA, 1992); the presence of others in our memory and the dynamics of daily communications.

In this sense, one can count on the independence of a historical and a social time (HALBWACHS, 2006), a very relevant score for social psychology (WINTREBERT, 2000; PAEZ, INSUA, VERGARA, 2002) between a collective / social memory that belongs to the group's own time (union of its members and the durability of the group) and history, which participates in a supposedly permanent social time, although any representation of the past (history, heritage, tradition, etc.) can also be considered as a real reconstruction (RICOEUR, 1998).

It is argued that individual memory and social / collective memory share the same social frameworks that would allow them to recompose a memory of the past according to its value in the society that possesses it (JAISSON, 1999) - it can be modulated according to the requirement of social conjecture (HAAS, 2002); but it can also be "a reconstitution of the present made under the influence of the past" (JAISSON, 1999, 167). In any case, this reconstruction of the past goes beyond the limits of human 'mnemic' capacity in an isolated dimension of being.

For this capacity is seen more on the side of the psychological and social processes related to social thought that govern beliefs, representations, and memories, and thus grant among them the traditions (which refer to the past, even subject to the effects of the actualization) and ideas (of the present) admitting only what corresponds to the situation and can still arouse interest and objective understanding: so that the past remains 'effective' in / to the present; it is the circumstances, ideological options, and positions socially valued at a moment in history that will give 'forgetfulness' a political dimension (in the broad sense of the term) sustained by a voluntary project and not by progressive amnesia (CIARCIA, 2002). 
The social memory is not, therefore, 'banally unfaithfup; it is essential the interest that can motivate any movement that tends to bring it closer to the social representations that, in turn, can be seen as forms of expression of social thought. However, in this social logic based on the relation "memory-time and society", the past is not only considered as a closed book, definitely written; it can be reinterpreted.

Because, the society, in its present, presents itself as a historical project of the past where everyone tries to live according to certain values that change throughout history. In this perspective, the difficulty of an interpretation of reality through historical determinism seems evident: each generation can (re) define and (re) appropriate the tradition in its own way. At any moment, one can see several pictures in the past. This is never linear, which makes complex the question of how 'fidelity' is given to historiography as a method, whose form seeks to ensure the construction of a verisimilitude narrative. In any case, the future of the past remains an open question.

\section{FROM THE COLLECTIVE/SOCIAL MEMORY TO CULTURAL MEMORY}

The notion of collective memory, which essentially addresses the question of the principle of social cohesion, assumes a singular role in the heterogeneous context of our contemporary societies. The public function of collective memory, in the form of celebrations or museums, as well as the evocation of traumatic memories for a given community, provokes a heated debate in a great number of fields of analysis, ranging from Cognitive Sciences to Political Sciences, Sociology, History and other disciplines of Social Sciences. For this is the great merit of the work of Paul Ricœur, "La mémoire, I'histoire, l'oubli', of having embraced in his reflections rich arguments from different fields of analysis.

However, what holds our interest in this consideration is less the diversity of perspectives than the author examines than the deep motivation that nourishes his conception on the notion of 'memory', emphasizing a moral reflection that goes through all the work. When returning to the presentation of the work, this motivation is clearly expressed:

\footnotetext{
I am disturbed by the disquieting spectacle which presents the excess of memory here, the excess of forgetfulness there, not to mention the influence of celebrations, and errors of memory - and forgetfulness. The idea of a just memory policy is, in this respect, one of my avowed civic themes (RICOEUR, 2007, p.17, our translation).
}

The intention, here enunciated, expresses a considerable ambition; in memory, in history, in forgetfulness, Ricœur's reflection (2007) raised by Leite (2015), does not only address the issues 
of memory or forgetfulness of the restricted individuals or groups, but of the political order in the fundamental sense of the term. It was concerned to identify a 'fair memory' with an authentic 'civic theme', involving a policy as a regulatory framework and expanding its reflection in the memory of the national communities and of the different groups that compose them, organized in ample political orders according to their contemporary conceptions.

However, Ricœur (2007) resists to the opposite tendency, which refuses personal experience to assume a status of 'authentic subject' in the elaboration of memories. This is demonstrated by the way he examines Halbwach's theory of collective memory, especially in the "social frameworks of collective memory." Halbwachs (2006) has shown that collective memory, far from being composed of a set of individual memories, is rather the foundation of personal memory and consciousness.

This analysis, as emphasized by Ricœur (2007), is to reduce the personal awareness of a collective source to the social frameworks from which it would belong: our social environment would act in us, whether conscious or not of its influence and, in this sense, our more intimate thoughts and forgetfulness

contain a network of community meanings outside of us. Halbwachs (2006) has shown that individual memory, however intimate it may be, is a social phenomenon. It is impregnated with early childhood by the collective memory of the group, from family to nation, in which a human being is born, grows and lives. Without these multiple relationships with the collective traditions of the different groups in which he participates, no individual is capable of developing a memory.

Posteriorly, the anthropologists Aleida Assmann (2006) and Jan Assmann (2008) differentiated the 'collective memory' with the notions of 'communicative memory' and 'cultural memory'. By the epithet 'communicative', a daily memory is assigned, which guides and directs the group and its members with the help of common and exemplary action models over time. The term 'cultural' means to evoke a long memory that retains collective guidelines and group identity images, and this ensures its actualization using the most diverse means, from ritual to symbol, from images / paintings to songs, stories and other cultural elements. This notion, from a broader level of its historical conception, satisfactorily captures a certain particularity in the diachronic dimension of collective memory.

Thanks to the dimension of cultural memory, individual memories are 'grafted' into the collective memory and entrusted, to some extent, to the social control of the community. All those who participate in this collective memory can thus confirm or falsify the dating of their personal memories (HALBWACHS, 1994). In this way, the most intimate personal memory is integrated within 
the framework of communicative memory, which is based, fundamentally on communication. In that regard, Assmann (2016, p.119, our translation) argues that:

\begin{abstract}
The communicative memory is not institutional; is not maintained by any institution intended to teach, transmit or interpret; it is not cultivated by specialists and is not convened or celebrated on special occasions; is not formalized or stabilized by any form of material symbolization; it lives in everyday interaction and communication, and for this reason alone has a limited depth of time, which usually reaches back in retrospect no more than 80 years, the period of three interacting generations. There are also structures, 'communicative genres', traditions of communication and thematization, and, above all, affective bonds that connect families, groups and generations.
\end{abstract}

In fact, communication is not just about confirming the dates and events that are remembered. The individual who remembers, joins the middle of the collective memory, marked by the social framework to which he is linked (HALBWACHS, 2006). This medium is formed by the community of people who share common interests and have substantially the same experiences. In this sense, the social operator is established in a community with the same affinities, which restricts the possible associations and, thus, guarantees a continuity and a certain historical constancy.

The question of whether a group as such can build a memory is the subject of debate. Some theorists consider that collective memory is the sum of individual memories; for others, it transcends them and is updated through institutions, monuments and social and cultural practices. Conciliating these points of view, social psychology conceives the collective memory bearers as socially and culturally situated beings, who use a set of vectors or cultural tools associated with their community (SÁ, 2012). Collective memory is therefore the product of an interaction between individual memories and the social practices and institutions that encompass them.

This last observation leads us to question the processes by which communicative and collective memories, with the traditions they transmit, lead to a cultural memory and a historical consciousness. If there is no culture without transmission, and transmission without organized memory, memory organization inevitably and precisely evokes the political imperative of memory when it is understood as a powerful tool of social transformation (SOARES; KISHI, 2009).

In consequence, the memory of the urban social space, with its conflicts between the oligarchy, the city and the various communities of memory, has been observed in contemporary times, which has revealed many takedowns, eliminations and suppressions, creators of official 'souvenir' (GONÇALVES, 2002). For those who say games of memory also say games of power and balance of power. Memories, 
such as forgetfulness are rarely innocent, can be biased because they are part of the decision-making processes of a social plan of any society.

This observation allows us to approach from another point of view the modalities of forgetting. In this sense, two approaches can be contemplated: 'organized' or simply biased oblivion, in relation to collective memory and structural amnesia, in relation to cultural memory (BURKE, 2000). Like collective memory, oblivion is conditioned by membership. It refers to the daily experience of competing inequalities, powers and the cultural phenomenon of defining norms and standards (HALBWACHS, 2006).

Assmann (2008) noted the close relationship between power and memory: power needs, retrospectively, an ascendancy and, prospectively, a will (or interest) to be reremembered, which leads to an alliance with memory. But when society is intersected by cultural inequalities, by class differences where the unprivileged aspire to change and forge a linear history by allowing an interpretation of memory whose logic attributes to change and ruptures a progressive value, power combines with forgetfulness and desperately seeks, through the control of communication in a broad sense, to prevent by structural amnesia the intrusion of history (ASSMANN, 2008).

Structural amnesia operates in cultural memory, through a reduction in the content of the group's history, a classification of some reasons for identification that are considered almost timeless and persistent (ABADIA, 2010). Thus, cultural memory shows an enormous capacity to forget the most complex fundamental developments and the most misleading important data.

The criteria of this selection, of 'selective memory', are based on the relation of historical data to the consciousness of identity or, simply, with the interests of the group (ASSMANN, 2008). Anything that threatens or disturbs the construction of group identity is repressed and forgotten. Both at the level of the identity function and at the institutional level, there may be a culture or an instrumentalized policy of some memories (GONÇALVES, 2002).

As Dantas (2012, p. 52) explains, memory can be seen in this sense as "a selective process of retention and continuous use of ideas, impressions, images, knowledge and experiences acquired and lived previously." In this way, structural amnesia operates in cultural memory a chronological concentration on central events considered decisive by society eager to remember. For remembering the past is crucial to our sense of identity: knowing what we have been confirming what we are (LOWENTHAL, 1998). 


\section{FROM THE CULTURAL MEMORY TO THE INFORMATION SOCIETY}

From Comte's (1972) perspective, in his studies on the fundamental laws of social phenomena, it can be argued that memory, as a social phenomenon, is not only a resource for the maintenance of traditions that tends to favor conformism to the past; but, also a social development resource through the constant search to bridge social gaps (OGÉCIME, 2016). This ambivalence does not, therefore, undo the memory, in its broadest sense, of its close relation with time-space, being a tool capable of creating "the consciousness of the past, which for its part is for many reasons essential to our wellbeing "(LOWENTHAL, 1998, p. 64).

From this consideration, the notion of culture, as a hierarchical, differential and generic concept (BAUMAN, 2012), can be evoked in its broadest sense as a set of distinctive, spiritual and material, intellectual and emotional traits that characterize a society or social group. It includes, in addition to arts and letters, lifestyles, basic human rights, value systems, traditions and beliefs (UNESCO, 2003). For each society and period has its own culture and admits, within it, different cultures. There is a multiplicity of cultures that meet, oppose, intermingle, and finally transform (Yudice, 2004; Garcia Canclini, 2005; Harvey, 2017).

However, the geopolitical order of the 1980s, characterized by scientific and technological progress, as well as the movement of people, goods, ideas, capital (CASTELLS, 2011; HALL, 2006; GARCIA CANCLINI, 1998) refers to the idea of a unification of time and space. This mondial /global conception is, to a certain extent, part of the so-called 'acceleration of history' to qualify the rapid evolution of the international society (TRIVINHO, 2007), regarding the universalization of betting, the advent of a world of economic, political and social interdependence and the necessary use of multilateralism to address these issues (CASTELLS, 2011; GARCIA CANCLINI, 1998).

From the representations trends of this great moment, Lowenthal (1998) evokes three types of sources of knowledge of the past: memory, history and fragments. In this sense, "the past simply as the past is totally unknowable," concludes Collingwood (1928, apud LOWENTHAL, 1998, p. 67), because "only the past preserved in the present is knowable" (LOWENTHAL, 1998, p. 67). This cognitive dimension of memory highlights the need to address the new conditions for the construction and transmission of knowledge, in which memory production occurs, which disrupt our fundamental cognitive organization whose tendencies, characteristics and cultures are attributed to the so-called 'Society of Information'. 
To illustrate briefly the origins of the 'Information Society' concept, three angles of analysis are immersed: the information society as an economic transition, a political project and social norms (OGECIME; MOURA, 2018). However, it is not sought to demonstrate, in particular, how each of these perspectives shapes social structure in modern times, but to emphasize how the use of technologies and information as a raw material in the daily operations of nations and societies has renewed practices and social and organizational dynamics.

As social norms, in the information society, information has taken new directions, going beyond maintaining a spirit focused on the availability and recovery of information from the processes of social redefinition and technical treatment (MATTELART, 2002); hence the role of memory institutions in the process of creating awareness of the past. For information as a raw material of knowledge (VERA, 2004), it becomes a resource of vital importance for human beings and for society "in all its ways of thinking, acting, communicating" (SHERA, 1973, p. 90 ).

And of its technological determinism (CASTELLS, 2011), this new society is based on a great convergence between computer science, telecommunications and audiovisuals. This convergence is made possible by the digitization of information, whatever it may be: sound, image, text, among others. Thanks to the digitization, that is to say, the translation in binary language, in the form of + or - electronics, of any information. For example, nothing distinguishes phone lines connecting computers around the world, a televised image of a digital file, or a conversation mediated by modern telecommunication tools. Every object, every product, book, museum, monument, has or will have its 'Multiplicative digital' (NEGROPONTE, 1995).

From the hypotheses of a new cognitive capitalism, where knowledge and flexibility remain key elements and lead to fundamental changes that are so many challenges, including the tendency of a paradigm shift of memory and oblivion justified by the reduction of costs and the increase of information storage capacities in digital format (CASTELLS, 2011). It is mainly evoked that it is less expensive to preserve digital information than to eliminate it, by default, any digitized information is 'naturally' stored somewhere (HULSTAERT, 2010). The argument is justified in the individual practices of each of us, for whom it has become less expensive and less laborious to preserve than to classify and eliminate certain digital documents (texts, images and sounds) that we produce, use or receive each day.

From the 'informationalism', introduced by Castells (2011), Schiller (2014) described the economic scale of the illicit market of information preserved in memory form for decision making in the CyberSociety. The giants of the web are not left behind; companies and applications like: Google, 
Whatsapp, Amazon, Facebook, etc. conserve the queries introduced in Internet search engines and data of various natures of the users with aggregated values to be transformed into commodities (TENE, 2008).

Personalized digital information perceived as a fundamental resource, a commodity that owes its "value" to the privilege of defining and predicting individual identities, behaviors, preferences, and risks that are systematically attributed to it (and to the correlative depreciation of the predictive character of structural variables or socioeconomic and environmental) (TENE, 2008). Therefore, most public or private bureaucracies bet on the automated processing of personal data for statistical purposes and / or profiling of consumers or potential consumers and citizens.

For the development and generalization of information and communication technologies establish an 'open' society characterized by the fluidity of trade and the porosity of the old microcosms (BOURDIEU, 1997). The openness and deterritorialization of the information society in relation to 'traditional' society (which was particularly marked by the idea of a strict separation between public and private spaces) radically transform the possibilities of human expressions and interactions, obsolete, a series of social norms that, in the traditional microcosms, were enough to solve problems of control of human behavior (JO STRANDBURG, RAICU, 2005).

In this way, the information space leads to a certain self-determination of the individual, where the identity would be less what would attest the components of a personality than a standard of intelligibility instituted and maintained socially.

\section{FOR A TECHNICAL MEMORY DIMENSION}

From the above considerations, it can be assumed that the obsession with individual / collective performance and to trigger socioeconomic processes, human beings create information systems capable of imitating the way they organize, process and execute information more quickly, in the form of memory, referring to the capacity of these technologies, creations of the human being and considered at the same time as human extension, to store information so that these can be recovered when they are sought to remind them.

These increasingly ubiquitous technological devices may at any time allow the reactivation of past action and events by recording data and information as resources and memory assets, abolishing even the temporal notions of the past and the present in a present eternal, an immediately accessible 
reality (ALLEN, 2008). In this way, it is necessary to emphasize that one of the characteristics of digital memory being, as it is discussed here, is its immediacy.

Since the emergence of 'ubiquitous computing' (or pervasive computing, a term used to describe the omnipresence of computing in people's daily lives) and 'environmental intelligence' (a view in which humans are surrounded by computing and networking technologies by the whole segment of their environment), prolonging or retransmitting in an almost prosthetic and disembodied form, the memory and the human intentionality point so much to the possibility of a progressive substitution of an automatic digital memory for incarnate or external memory as for the capacity of organic oblivion , which is consubstantial (ISTAG, 2006; FOUCAULT, 2013).

The primacy focused on personal information as a new category, a new feature in the same way that energy was in the Industrial Age. This new resources completes tacitly the processes of information and communication in a manner modeled on market relations and oriented towards the production of a certain distant marginal capital, while it becomes urgent - given the impact of the entry into the information society on subjectivation - to refine these processes in human-centered value systems (GARCÍA SELGAS, 2010).

This means that the impressions of which this society is made, are those of the body. The world is now constituted through machines, and bodies are massively occupied by fabricated temporary objects that cancel out any possibility of participation. Collective retentions and their framework shape the forms of participation (STIEGLER, 2008).

From the hyper-industrialization of the sensible, the propositions of an 'organology' of the internal elements and their transduction within the aesthetic sphere show that any evolution of a technical object reflected on the coming components of the organic bodies and the social body. This configuration of consciousness "reaches the industrial production of temporal objects at such a stage that the transformation of this consciousness can lead to their pure and simple destruction" (STIEGLER, 2004, p. 21, our translation).

The hyper-industrial era, called by Stiegler (2008), is characterized by the implantation of a new stage of control of the process of psychic and collective individuation. The individual becomes a consumer of a network that he consumes and consumes at the same time. This perspective, based on the paradigm of the object-oriented ontology, seems to reduce the notion of culture and in the dialectics. In it, hyper-industrialization of memory seems to be synthesized at two extremes: a programming of the affects by a standardization of 'noesis', a communitization of the affections and by an advancement 
of the genetic layers through the bottleneck in the somatic layers (STIEGLER, 2008). In this regard, the author Stiegler (2005, p. 118, our translation) argued that:

Human integration at the aesthetic level is based on purely symbolic references accepted by society from a rhythmic convention that encompasses days and distances in an artificial network. The play between time and space and time between space and domestic time remained quite broad until recently, except in urban areas where the fully humanized framework has always been the guarantee of the effectiveness of the urban device. The infiltration of urban time was made in a few years, first at long intervals by the regular periodicity of the transport and now it adapts to the details of the days by the normalization of the time to the rhythm of the radio and television broadcasts [...].

This brings about a certain social collapse that, in turn, generates a primordial narcissism: the individual conscience supported by the others (STIEGLER, 2008). Thus, in order to synchronize the consciousness, primordial narcissism must be repressed. The consciousness no longer sustains itself to the extent that it has been supported by others. This fundamental otherness of feeling, as of consciousness, is the guarantee of its becoming. In this sense,

\begin{abstract}
a super-humanized time and space would correspond to the ideally synchronous functioning of all specialized individuals, each in its function and its space. Through space-time symbolism, human society would rediscover the organization of the most perfect animal societies, those in which the individual exists only as a cell ... The bodily and cerebral evolution of the species still seemed to allow it to escape the fate of the ant tools and memory outsourcing. It is not forbidden to think that the freedom of the human individual represents only one stage, and that the domestication of time and space entails the perfect subjection of all particles of the supraindividual organism (Leroy-Gourha, 1965, our translation).
\end{abstract}

To confront these seemingly absolute logics, or to transform this framework a priori, it is all the more urgent that it, if it has no objective validity, has a performative power. The processes of subjugation in the advanced stage of the information society seem similar to the process of formation of subjective identities by the mechanisms of interpellation suggested by Althusser (1970). For, it appears that, particularly, through the interpellation that is directed to them through mechanisms of monitoring and control, through the social networks to which they are invited to participate, through operations of definition of profile that allow a growing individualization of consumer offers of goods and services, that individuals constitute or receive their identities.

The rigid attribution of their own traits in the name of an identity destiny that suggests a performative readability of the future of the 'profiled' individual that has become predictable; this refers exactly to the term 'digitized individual' in a paradigm in which the real becomes a copy of its own image (WEIBEL, 2002). The possibility of forgetting and being forgotten, therefore, would directly concern itself with social and political vitality. It was in this sense that Arendt (1994, p. 314) argued that: 
The miracle that saves the world, the field of human affairs, of natural ruin is finally the fact of the birth in which the faculty of action is rooted ontologically. In other words: it is the birth of new men, the fact that they begin again, the action that they are capable by right of birth (our translation).

From these considerations, if it is understood that technique, becoming a memory technology and implementing a generalized and global process of memory industrialization, now saturates all social, economic, political, religious, aesthetic and even vital frameworks, all the thinking with whom we consider our identity as men, that is, social beings and our living environment as a whole.

\section{FINAL CONSIDERATIONS}

From the foregoing considerations, it can be said that the concept of memory is so broad that at the moment of contextualizing it, it would be obvious to define it, to draw its boundary line with certain other concepts and its tangential dimension in certain acts of social operations. Memory sometimes appears as a concept, but also as a mere adjuvant or a resource for the apprehension of another concept at other times.

The contributions on the interdisciplinary concept of memory emphasize social functions and organizational strength, transmission and safeguarding of resources, techniques, memory operators in the communities that share them. Then, if culture is a factor of social cohesion; memory is its vector or its variable. In contemporary societies, the demand for collective representations is a means that power holders increasingly use to legitimize their actions, perpetuate their influence, mobilize minds, and so on.

Memory from the perspective of the individual over time is considered as a plastic and changing capacity, depending on the needs and experiences of each stage of life. And within a social practice, memory is the variable that can give society the ability to guarantee the well-being of all its members, reducing disparities and avoiding marginalization. And its ( $\mathrm{re}$ ) configuration in the imaginary structure organizes the perception, interpretation and management of the present.

The function of memory, as a kind of perpetuation of space-time, inextricably links it with history. Memory seems, in this sense, as a kind of representation of the past (places of memories: museum, archives, libraries; data and information in its various levels and contexts, etc.). Therefore, if history aspires to verisimilitude; the memory refers to the respect for fidelity, however, it is necessary to recognize that it (the memory) has too many gaps that are part of the 
rememoration. Memory, as an object of history, may perhaps be observed with the crossed eyes of a historical method that allows one to distinguish individual and collective memories according to historical spaces and times.

Memory is an active resource for rebuilding and rethinking the present from past images. From this consideration, we can emphasize the cognitive essence of memory. In the information society, the new conditions of circulation of knowledge disturb our cognitive organization fundamentally. From these modernist theoretical foundations of this new mode of society, mankind is supposed to have experienced three major technological revolutions: the invention of writing, the invention of printing, and the current revolution in computers and the Internet. These three revolutions have modified our relationship with knowledge, externalizing more and more memory and knowledge, and compromising and objectifying our cognitive abilities for tasks of invention and imagination from other devices.

In the 21 st century, the dimension of memory is oriented towards the conquest of the memory of consumers, because the control of markets is the control of behavior. Behaviors are conditioned by memories. In contemporary times, genetic memory, genetically modified organisms, etc., become technical. Social and collective memories are placed on social networks by institutions / companies through digital technologies. Machine memory is crucial because it allows for productivity gains, automation, and the social reorganization of labor within capitalist societies. Thus, in order to trigger socio-cultural and political-economic activities, memory in all its dimensions is now industrialized, exploited and systematically rationalized.

\section{REFERENCES}

ABADIA, Lília. A identidade e o patrimônio no Brasil. Universidade de Lisboa, Faculdade de Letras, Departamento de Estudos Anglísticos, Lisboa, 2010. Disponível em: http://repositorio.ul.pt/ bitstream/10451/2259/2/ulfl078272_tm.pdf. Acesso em: 20 de novembro de 2017

ALLEN, Anita. Dredging-Up the past: life-logging, memory and surveillance. University of Chicago Law Review, 2008.

ALTHUSSER, Louis. Idéologie et appareils idéologiques d’État. La Pensée, juin 1970, pp. 3-38.

ARENDT, Hannah. Condition de l'homme moderne. Calman-Levy, collection, Agora Pocket, 1994

BOURDIEU, Pierre. A miséria do mundo. Tradução de Mateus S. Soares Azevedo et al. 5 ed.

Petrópolis, RJ: Vozes, 1997. 
ASKEVIS-LEHERPEUX, F. La mémoire des personnes: le rôle des attentes. In J.P. Leyens et J.L. Beauvois (sous la direction de). L'ère de la cognition. Grenoble, presses Universitaires de Grenoble, 1997. p. 91-105.

ASSMANN, Aleida. Memory, individual and collective. In: GOODIN, Robert E.; TILLY,Charles (Ed.). The Oxford handbook of contextual political analysis. Oxford: Oxford University Press, 2006. p. 210-224.

ASSMANN, Jan. Communicative and Cultural Memory. In: ERLL, Astrid; NÜNNING, Ansgar (Ed.). Cultural Memory Studies: An International and Interdisciplinary Handbook. Berlin: Walter De Gruyter, 2008. p. 109-118.

ASSMANN, Jan. Memória comunicativa e memória cultural. Tradução: Méri Frotscher. História Oral, v. 19, n. 1, p. 115-127, jan./jun. 2016.

BAUMAN, Zygmunt. Cultura como conceito. In: Ensaios sobre o conceito de cultura. Rio de Janeiro: Zahar, 2012, p.83-154.

BROWN, R; Kulik, J. Flashbulbs memories. Cognition, 5, 1977. p. 73-99.

BURKE, Peter. Variedades de história cultural. São Paulo - Rio de Janeiro: Civilização Brasileira, 2000.

BUTLER, Judith. Undoing Gender. Traducción: Patrícia Soley-Beltran. Routledge, New York, 2006.

CASTELLS, Manuel. A sociedade em rede: a era da informação: economia, sociedade e cultura. Volume 1. Paz e Terra, São Paulo, 2011.

CIARCIA, G. Notes autour de la mémoire dans les lieux ethnographiques. Ethnologies comparées, no 4, 2002. pp. 1-17.

COMTE, Auguste. La science sociale. Paris : Éditions Gallimard, Collection Idées nrf., $\mathrm{n}^{0} 261$, France, 1972. 308 pages.

DANTAS, F. S.. Direito fundamental à memória. Curitiba: Juruá Editora, 2012, p. 52-85.

DE SAUSSURE, Ferdinand. Cours de linguistique générale. Wiesbaden, Harrassowitz, 1968.

EDWARDS, D.; MIDDLETON, D. Joint remembering: constructing an account of shared experiences through conversationnal discourse. Discourse Processes, 9, 1986. pp 3-19.

FOUCAULT, Michel. 0 corpo utópico, as heterotopias. 1.ed. Tradução: Salma Tannus Munchail, N-1 Edições, 2013.

GARCIA CANCLINI, Néstor. Diferentes, desiguais e desconectados. In: Diferentes, desiguais e desconectados: mapas da interculturalidade. Rio de Janeiro: EDUERJ, 2005, p.55-103.

GARCIA CANCLINI, Néstor. Culturas híbridas: estratégias para entrar e sair da modernidade. 2. ed. São Paulo: EDUSP, 1998. 
GARCÍA SELGAS, Fernando J. Posthumanismo, sociedad y ser humano. Presentación. Athenea Digital. Revista de pensamiento e investigación social. Número 19, 2010.

GONÇALVES, José Reginaldo Santos. A retórica da perda: os discursos do patrimônio cultural no Brasil. 2. ed. Rio de Janeiro: UFRJ ; Iphan, 2002.

HAAS, V. Approche psychosociale d'une reconstruction historique. Le cas vichyssois. Cahiers internationnaux de psychologie sociale, 53, 1, 2002, p. 32-45.

HALBWACHS, Maurice. A memória coletiva. São Paulo: Centauro, 2006.

HALBWACHS, Maurice. Les cadres sociaux de la mémoire. Paris: Albin Michel, 1994. (Originalmente publicado em 1925).

HALL, Stuart. A questão pós-colonial. In: Da diáspora: identidades e mediações culturais. Belo Horizonte: UFMG, 2006, p.49-94.

HARVEY, David. Passagem da modernidade à pós-modernidade na cultura contemporânea. In: Condição pós-moderna: uma pesquisa sobre as origens da mudança cultural. São Paulo: Loyola, 2017, p.13-113.

HOULT, T. F, ed. Dictionary of Modern Sociology, 1969. In UGORJI, Basil. From cultural Justice to Inter-Ethnic Mediation: A reflection on the possibility of Ethno-Religious Mediation In Africa.Outskirts Press, v3.0, USA, 2012.

HULSTAERT, Arnaud. Préservation à long terme de l'information numérique. Rendre l'information accessible durablement. Smals, Clients et services. Sections Recherches, Bruxelles, 2010.

ISTAG. Information Society Technologies Advisory Group. Shaping Europe's Future Through ICT, Commission Européenne, March, 2006.

IZQUIERDO, Ivan. El Arte de Olvidar. Editorial: Edhasa. España, 2008.

IZQUIERDO, Ivan. Memórias. Estud. av. vol.3 no. 6 São Paulo May/Aug. 1989.

JACINTHO SETTON, Maria da Graça. A teoria do habitus em Pierre Bourdieu: uma leitura contemporânea. Universidade de São Paulo, Faculdade de Educação. Maio/Jun/Jul/Ago, N ${ }^{0}$ 20, São Paulo, 2002. Disponível em: < http://www.scielo.br/pdf/rbedu/n20/n20a05>. Acesso em 20 de jan. 2019.

JAISSON, M. Temps et espace chez Maurice Halbraws (1925-1945). Revue d'histoire des sciences humaines, 1,1999. Pp.163-178.

JO STRANDBURG, Katherine; RAICU, Daniela. Privacy and technologies of identity: a crossdiscriplinary Conversation, Springer, 2005.

KREBS, Clausia; WEINBERG, Joanne; AKESSON, Elizabeth. Neurociências ilustrada. Artmed, 2013.

LEITE, Verônica Gomes Olegario. Memória e violência: o conflito armado do peru sob a ótica da literatura. Universidade Federal de Minas Gerais, Belo Horizonte, 2015. 
LOWENTHAL, David. Como conhecemos o passado. Tradução: Lúcia Haddad. Proj. História, São Paulo, (17), nov. 1998.

MATTELART, Armand. História da sociedade da informação. São Paulo: Loyola, 2002.

NEGROPONTE, Nicholas. Being Digital. Trad. Marisa Abdala. Ediciones B, S,A., Barcelona, 1995.

NICOLAS, S. La mémoire humaine: une perspective fonctionnaliste. L'Harmattan, Paris, 2000.

OGÉCIME, Mardochée; MOURA, Maria Aparecida. Políticas de informação para a sociedade da informação e do conhecimento: Elementos constitutivos, dimensões e análise na perspectiva da ciência da informação In: XIX ENANCIB ENCONTRO NACIONAL DE PESQUISA EM CIÊNCIA DA INFORMAÇÃO, 19., 2018, Londrina. Anais... Londrina, 2018.

OGECIME, Mardochée. Um olhar sobre políticas da informação na sociedade contemporânea. Dissertação (Mestrado) - Universidade Federal da Bahia, Instituto de Ciência da Informação, 2016.

PAÉZ, Deschamps; INSUA, Pennebaker; Vergara, A. Relations sociales, représentations sociales et mémoire. Bulletin de psychologie, XLV, no 405, 1992. p. 257-263.

RICOEUR, Paul. Memória e imaginação. In: A Memória, a História, o Esquecimento. Campinas: Ed. Unicamp, 2007, p.25-70.

RICOEUR, Paul. La maruqe du passé. Revue de métaphysique et de la morale. Paris, 1998. p. 1, 7-31.

SÁ, CP. Psicologia social da memória sobre memórias históricas e memórias generacionais. São Paulo, 2012.

SCHILLER, Dan. Geopolítica da espionagem: as ramificações do Caso Edward Snowden. Le Monde Diplomatique, Brasil. 2014.

SCHOFIELD, John; SZYMANSKI, Rosy. Local heritage, global context: cultural perspectives on sense of place. Ashgate Publishing, Ltd. New York, 2011.

SEBASTIÁN et. al. La necesidad de políticas de información ante la nueva sociedad globalizada. El caso Español. Ci. Inf., Brasília, v. 29, n. 2, p. 22-36, maio/ago. 2000.

SHERA, Jesse. Epistemologia social, semântica geral e biblioteconomia. Ciência da Informação, Rio de Janeiro, v. 2, n. 2, p. 87-97, 1973.

SOARES, I. V. P.; KISHI, S. A. S. (Orgs). Memória e verdade: a justiça de transição no Estado Democrático Brasileiro. Belo Horizonte: Fórum, 2009, p. 55-67.

STIEGLER, Bernard. Lieu, mémoire et technique. Philo Cité. France, 2008.

STIEGLER, Bernard. De la misère symbolique: Tome I. L'époque hyper-industrielle. Editions Galilée Incises. Paris, 2004. 
STIEGLER, Bernard. De la misère symbolique: Tome II - La catastrophè du sensible. Galilée, Paris, 2005.

TENE, Omer. What Google knows: privacy and Internet search engines. Express 0, 2008.

TIBERGHEIN, $G$ et al. Contraintes structurales et fonctionnelles des systèmes de traitement. In J.F.Richard, C. Bonner et R. Ghiglione (sous la direction de), Traité de psychologie cognitive, t. 2, 1990. pp. 1-32.

TRIVINHO, Eugênio. Dromocracia, cibercultura e transpolítica. In: _. A dromocracia cibercultural: Lógica da vida humana na civilização mediática avançada. São Paulo: Paulus, 2007. p. 46-87.

UNESCO. La UNESCO y la cumbre mundial sobre la sociedad de la información, Suíça, 2003.

VERA, Roberto Garduño. La Sociedad de la Información en México frente al uso de Internet. Revista Digital Universitaria, UNAM, Vol.5, No. 8, p.4. México, 2004.

WEIBEL, Peter. Pleasure and Panoptic Principle. in LEVIN, Y. Thomas; FROHNE, Ursula;

WEIBEL, Peter. CTRL Space: rhetorics of surveillance from Bentham to Big Brother. MIT Press, 2002.

WINTREBERT, R. Mémoire de groupe et représentations collectives. Actes de la $5 \mathrm{e}$ conférence sur les représentations sociales, Montréal 29 aout - 2 septembre. Canada, 2000.

YÚDICE, George. A conveniência da cultura: usos da cultura na era global. Belo Horizonte: UFMG, 2004. (Humanitas). 